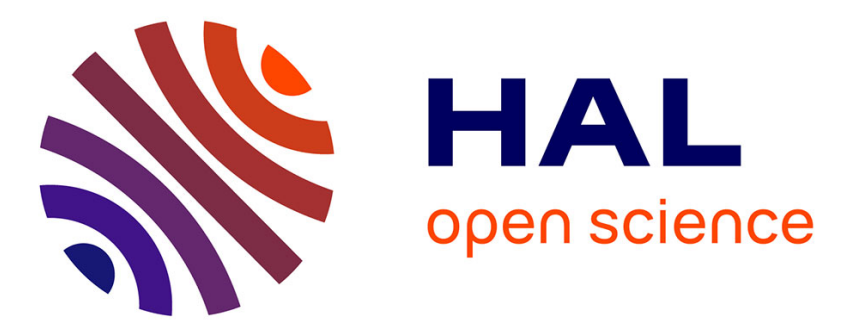

\title{
PICOSECOND PULSES FROM UV TO IR USING SPECTRO-TEMPORAL SELECTION DYE LASER
}

M. Martin, F. Nesa, E. Bréhéret, Y. Meyer

\section{To cite this version:}

M. Martin, F. Nesa, E. Bréhéret, Y. Meyer. PICOSECOND PULSES FROM UV TO IR USING SPECTRO-TEMPORAL SELECTION DYE LASER. Journal de Physique Colloques, 1987, 48 (C7), pp.C7-586-C7-586. 10.1051/jphyscol:19877140 . jpa-00226961

\section{HAL Id: jpa-00226961 https://hal.science/jpa-00226961}

Submitted on 1 Jan 1987

HAL is a multi-disciplinary open access archive for the deposit and dissemination of scientific research documents, whether they are published or not. The documents may come from teaching and research institutions in France or abroad, or from public or private research centers.
L'archive ouverte pluridisciplinaire HAL, est destinée au dépôt et à la diffusion de documents scientifiques de niveau recherche, publiés ou non, émanant des établissements d'enseignement et de recherche français ou étrangers, des laboratoires publics ou privés. 


\title{
PICOSECOND PULSES FROM UV TO IR USING SPECTRO-TEMPORAL SELECTION DYE LASER
}

\author{
M.M. MARTIN, F. NESA, E. BREHERET and Y.H. MEYER \\ Laboratoire de Photophysique Moléculaire, Bât. 213, Université \\ de Paris Sud, F-91405 Orsay Cedex, France
}

\begin{abstract}
High power single puises are produced, starting from one standard 8 ns Nd:YAG laser, by the two-stage spectro-temporal selection method in a dye laser system (1). A first dye oscillator gives 150 ps pulses which are used after amplification to pump a nultimode microcavity $(100$ to $200 \mu \mathrm{m})$. By filtering the emission of a single mode in the "blue" wing at $605 \mathrm{~nm}$, an almost bandwidth-limited, 1.5 to 4 ps os pulse is selected and amplified up to $0.3 \mathrm{~mJ}$. The complex time shape of the emisssion from the multimode cavity without selection is studiec with a streak camera and by autocorrelation. The latter shows a subpicosecond modulation, due to mode beat, within a single (amplified) spike.

Production of ps pulses at any frequency in a continuum from near-UV to near-IR is obtained by focusing these high power ps laser pulses in water. The effect of subpicosecond modulation of the multimode pulse on the efficiency and spectrai shape of the continuum generation by self-phase modulation is studied. A transient quenching effect of the continuum generation by successive pulses in water is observed.

Direct conversion of the powerful ps laser pulses at $605 \mathrm{~nm}$ into red or near-IR ps pulses is also obtained by a simpie technique involving Stokes shift in dyes and traveiling wave amplification.
\end{abstract}

(1) Y.H.MEYER M.M.MARTIN E.BREHERET O.BENOIST D'AZY in "IJ trafast Phenomena $y^{\prime \prime}$ p.39 Ed. Fleming and Siegman, Springer Verlag (1986). 